\title{
A várandós nő parodontalis egészségi állapota és a terhességi komplikációk közötti kapcsolat*
}

\author{
Gera István dr. \\ Semmelweis Egyetem, Fogorvostudományi Kar, Parodontológiai Klinika, Budapest
}

\begin{abstract}
Az elmúlt két évtizedben publikált epidemiológiai és klinikai tanulmányok bizonyos összefüggéseket tártak fel a fogágybetegség és a koraszülés, valamint az alacsony születési testsúly incidenciája között. Bár ezeknek a vizsgálati eredményeknek az evidenciafoka elég alacsony, ennek ellenére ma az irodalom a fogágybetegséget a terhességi komplikációk egyik független, befolyásolható rizikótényezőjeként tartja számon. A jelen közlemény célja összefoglalni a parodontalis gyulladásnak a terhességi komplikációkra gyakorolt hatásával kapcsolatos legújabb epidemiológiai és klinikai eredményeket és megkísérelni a kapcsolat mögött rejlő biológiai mechanizmusok feltárását. Az epidemiológiai és klinikai vizsgálatok túlnyomó többsége arra a konklúzióra jutott, hogy a várandós anyák rosszabb parodontalis statusa bizonyos negatív hatással van a magzati fejlődésre és a születési testsúlyra, valamint fokozza a koraszülés, a praeeclampsia és a halvaszületés incidenciáját. Eddig az ezzel foglalkozó irodalomban két lehetséges biológiai mechanizmust mutattak ki: 1) a parodontalis baktériumok és azok toxikus termékei direkt hematogén szóródás révén érik el a placentofoetalis szöveteket, illetve 2) olyan indirekt mechanizmusok, amelyekben a parodontalis gyulladás következtében megemelkedett cirkuláló gyulladásos mediátorok váltanak ki másodlagos gyulladást az amnionban, és okoznak magzati károsodást. A második és harmadik trimeszter során alkalmazott parodontalis kezelésról nem sikerült megnyugtatóan igazolni, hogy csökkentené a terhességi komplikációk incidenciáját. A termékeny korban levő nők esetében profilaxisorientált szemléletnek kell meghonosodnia, miszerint gyermekvállalás előtt kell a parodontalis kezelést megejteni a jövőbeli várandós anya és magzata egészségének megőrzése érdekében.
\end{abstract}

Orv Hetil. 2018; 159(25): 999-1007.

Kulcsszavak: fogágybetegség, koraszülés, alacsony születési testsúly

\section{The association between maternal periodontal health and adverse pregnancy outcomes}

Data from epidemiological and clinical studies published in the past two decades indicate certain association between periodontal disease and increased risk for preterm birth or low birth weight. Although the strength of those observed associations is weak, periodontitis today is considered as one of the potentially modifiable risk factors for adverse pregnancy outcomes. The aims of the publication are to summarize the epidemiological and clinical evidence for the impact of periodontal disease on adverse pregnancy outcomes and to make an attempt to overview the potential biological mechanism behind this association. The majority of epidemiological and clinical studies found certain negative effect of poor maternal periodontal condition on the incidence of low birth weight, preterm birth, pre-eclampsy, restricted foetal growth or even stillbirth. Two possible biological pathways have so far been identified: 1 ) the direct dissemination of the periodontal pathogens or their toxic by-products which reach the foetal-placental unit, and 2) an indirect mechanism when the circulating systemic inflammatory mediators induced by the periodontal inflammation can provoke secondary inflammation and foetal damage in the amnion. The periodontal therapy applied during the second or third trimesters has not been proven to reduce the incidence of any adverse pregnancy outcomes in pregnant women. A much more prophylaxis-oriented approach in periodontal treatment is needed. The adequate periodontal therapy should be completed before the conception to provide benefit to the pregnant women and also the new born baby.

Semmelweis Ignác születésének 200. évfordulója évében a Szerkesztőség felkérésére készített tanulmány.

*A közlemény megírását a European Federation of Periodontology 2018. évi európai „Oral Health and Pregnacy” kampánya inspirálta. 
Keywords: periodontal disease, preterm birth, low birth weight

Gera I. [The association between maternal periodontal health and adverse pregnancy outcomes]. Orv Hetil. 2018; 159(25): 999-1007.

(Beérkezett: 2018. február 18.; elfogadva: 2018. március 25.)

\section{Rövidítések}

CRP = C-reaktív protein; Ig = immunglobulin; LPS $=$ lipopoliszacharid; $\mathrm{PMN}=$ polymorphonuclearis; $\mathrm{TNF}=$ tumornekrózis-faktor

Egy amerikai fogorvos, nevezetesen W. D. Miller 1891ben "The human mouth as a focus of infection" (Az emberi száj mint az infekciós góc) című közleményében arra a következtetésre jutott, hogy az „orális fokális szepszis" (infekció) testszerte más gyulladásos betegségek oka lehet [1]. Ezt követően a góckutatásban voltak kiemelkedő és látens periódusok, azonban az orális gócbetegség teória ismételten csak az 1990-es években került a kutatások középpontjába, amikor a World Workshop in Periodontics megalkotta a ,periodontal medicine” fogalmát [2]. Az 1980-as évek vége óta felhalmozódott epidemiológiai és klinikai követéses vizsgálatok alapján ma már kellő információ áll rendelkezésre ahhoz, hogy a szakmai körök elismerjék a krónikus parodontalis gyulladást több szisztémás krónikus betegség egyik rizikófaktoraként [3]. Idesorolható a bacteriaemia, a terhességi komplikációk, az arteriosclerosis, a cardiovascularis betegségek, a diabetes, az infectiv endocarditis és a légzőszervi betegségek $[3,4]$.

Ahhoz, hogy megértsük a parodontalis infekció és az úgynevezett „parodontalis góc” szisztémás hatásait, röviden át kell tekinteni a parodontalis gyulladásról vallott legújabb ismereteinket. A szájüreg szervezetünk legkomplexebb commensalis bakteriális flórájának otthona. Eddig különböző tenyésztési és molekuláris biológiai módszerekkel több mint 700 orális baktériumot, illetve ezek klónjait mutatták ki. Ezek többsége ártalmatlan szaprofita, de még az egészséges száj is hordoz, alacsony százalékban, patogén mikrobákat. A nyálkahártya felszínét borító hámsejtréteg folyamatos és nagyon gyors megújulása gátját szabja tartós bakteriális kolóniák megtapadásának. A szájüreg az egyetlen olyan terület az emlősszervezetben, ahol fiziológiás körülmények között is vannak olyan felszínek, amelyek nem újulnak meg, nem lökődnek le, és nem biztosítanak hatásos öntisztulási mechanizmust. A szájüregben lévő kemény képletek, a fogak, különböző tömések és fogpótlások olyan állandó, nem megújuló felszínrendszert alkotnak, amely lehetővé teszi tartós, jól szerveződött, érett bakteriális kolóniák megtapadását és fejlődését. Az ezeken a felszíneken megtapadt bakteriális vegetáció és ezek bomlástermékei tehetők felelőssé a caries, a gingivitis és parodontitis, vala- mint a periimplantitis vagy éppen a múfogsor lemeze alatt kifejlődő stomatitis kialakulásáért. A bakteriális kolónia (dentalis biofilm) csak mechanikai eszközökkel távolítható el [5].

Egészséges állapotban a szervezet és a bakteriális ökoszisztéma között egyensúly van. Ilyenkor vagy a biofilm mennyisége és a patogén törzsek aránya csekély, vagy a szervezet immunválasza képes neutralizálni még az erős negatív hatásokat is. Ennek az egyensúlynak kell felborulnia ahhoz, hogy fogágybetegség alakuljon ki. A gyulladásos láncreakció aktiválódásának előfeltétele, hogy a sulcusban lokálisan normál bakteriális flóra eltolódjon olyan patogén bakteriális közösség irányába, amelyben már többségben lesznek a szervezetre ártalmas, destruktív immunválaszt gerjesztő baktériumok [6]. A fogágybetegséggel társuló subgingivalis bakteriális mikroflórát csaknem kivétel nélkül Gram-negatív obligát vagy fakultatív anaerob baktériumok alkotják. A flóra legagresszívebb tagjai: Aggregatibacter actinomycetemcomitans, Campylobacter rectus, Filifactor alocis, Fusobacterium nucleatum, Prevotella intermedia, Porphyromonas gingivalis, Tannerella forsythia, Treponema denticola [7, 8]. Ma már egyértelmú, hogy a tapadásveszteséggel járó destruktív parodontitis egyik, de nem egyedüli etiológiai tényezője a dentalis biofilm. Ugyanakkor a destruktív folyamat kifejlődéséhez mindig szükség van arra, hogy bizonyos specifikus patogén mikroorganizmusok domináns szerepet kapjanak ebben a bakteriális ökoszisztémában [5]. Egyértelmú az is, hogy az orális bakteriális ökoszisztéma és a szervezet helyi és általános specifikus és nem specifikus védekezőrendszereinek komplex kölcsönhatása szabja meg a gyulladásos folyamat lefolyását, a pusztulás mértékét és a kezelés sikerét is [5]. A tömeges dysbioticus kórokozó mikroflóra és ezek virulens toxikus termékei, proteolitikus enzimei, a leukotoxin- és az endotoxinrendszer (lipopoliszacharid [LPS]) aktivizálja, vagy éppen blokkolja a helyi immunválaszt [9].

A gingivalis sulcusepithelium és a dentritikus sejtek felszíni receptorai felismerik a patogén behatolókat, és bizonyos specifikus jelátvitel révén lokálisan aktivizálják az immunrendszert abból a célból, hogy eliminálják a patogén baktériumokat, és helyreállítsák a szervezetmikroba homeosztázist. Fogékony egyénekben azonban a baktériumok immunrendszert megtévesztő tulajdonságai és/vagy bizonyos immunreguláló defektus révén képesek a tasakban tartósan megtelepedni és a szövetekbe behatolni. A subgingivalis bakteriális biofilm akár évtizedekig perzisztálhat a tasakban, annak ellenére, hogy a 
sulcusfolyadékba a gyulladt tasakfalból nagyszámú polymorphonuclearis (PMN) leukocyta lép ki, magas a komplementkoncentráció, és a tasakfalban felszaporodó plazmasejtek tömegesen termelnek IgM- és IgG-molekulákat $[5,6,10]$. Mivel azonban lokálisan a humorális immunválasz sejtjeinek többségét az LPS alternatív úton képes aktivizálni, a B-sejtekből képződő plazmasejtek által termelt immunglobulinok nem ismerik fel az antigént, nem kötődnek hozzá, nem vesznek részt az opszonizációban sem. Ezek a proteinmolekulák inkább táplálékul szolgálnak a tasak anaerob, proteolitikus baktériumai számára. A tasakban akár évtizedekig háborítatlanul perzisztáló biofilmbaktériumok egy része szöveti invázióra képes, behatol a parodontalis szövetekbe, és a tasakfalon keresztül a véráram útján állandóan kommunikál a szervezettel is. Generalizált krónikus parodontitisben, minden fog mentén 4-5 mm mély tasakot feltételezve, összességében közel tenyérnyi nyitott sebfelszínnel kell számolnunk, amelyen keresztül a legagresszívebb obligát anaerob, endotoxint termelő bakteriális közösség állandó kontaktusban van a szervezettel [5].

A szövetpusztulás során a parodontiumban lokálisan nagy mennyiségű gyulladásos mediátor és enzim termelődik. A gyulladásos citokineket - például interleukin (ILl és IL6) - nem csupán a hámsejtek, fibroblastok, neutrophyl és macrophag sejtek expresszálják, hanem a gyulladás krónikus szakában már a lymphocyták is termelik [9]. Az ILl és az IL6 fontos szerepet játszik a gyulladásossejt-migrációban és az osteoclastogenesisben is. Ezek direkt vagy indirekt módon aktivizálják az osteoclast sejteket, ami alveolaris csontreszorpcióhoz vezethet. Ezenfelül a prosztaglandin- $\mathrm{E}_{2}\left(\mathrm{PGE}_{2}\right)$ is érintett minden lokális és szisztémás gyulladásban és a csontreszorpcióban is [9]. Tehát a nem kezelt, és egyre mélyüló parodontalis tasakban hihetetlenül komplex, zömében Gram-negatív anaerob bakteriális közösség perzisztál. A 2-3 mm-nél mélyebb tasak esetén a fogmosásnak vagy a legújabb generációs antibakteriális öblítőszereknek (klórhexidin, esszenciális olajok) sincs hatásuk, hiszen a subgingivalis biofilmet nem érhetik el. Másrészt az antibiotikus kezelés sem adhat tartós eredményt, mivel az antibiotikumok sem képesek a biofilm mélyebb rétegeit elérni, éppen azt a zónát, ahol a legagresszívebb obligát anaerobok szaporodnak. A subgingivalis biofilm csak sebészi, mechanikai eszközökkel, subgingivalis kürettálással távolítható el. Ha ezt nem tesszük meg, ez a krónikus gyulladásos állapot akár évtizedekig fennállhat, és extrém esetben a fog végül kilazul, és a szervezet spontán megszabadul a gyulladt góctól [5].

Ugyanakkor nem csupán a parodontalis infekció lehet hatással a terhesség kimenetelére, hanem a terhesség is komoly hatással van a szájüregre. A szájüreg az egyik legfontosabb terület, ahol terhesség során a szexuálishormon-változások manifesztálódnak. A terhességi gingivitis a leggyakoribb orális elváltozás, amely várandós anyákban előfordulhat.
A terhességi gingivitis gyakori betegség, amelyet az American Academy of Periodontology 1999. évi, ma még mindig érvényben lévő klasszifikációs rendszerében a plakk okozta szisztémás módosítófaktorokkal társuló ínybetegségek csoportjába soroltak [5]. Jellemzője a vöröses íny, amely könnyen vérzik, a megduzzadt ínyszél, az interdentalis papilla hyperplasiája, amely végül áltasakok kialakulásához vezet. Különböző irodalmi adatok szerint a terhességi gingivitis a várandós anyák 30-100\%át érinti [11].

A terhességi gingivitis klinikai képe nem sokban különbözik a közönséges gingivitisétől, csak az a különbség, hogy már viszonylag csekély plakkmennyiség mellett is sokkal súlyosabb gyulladásos reakció alakul ki $[5,11]$. A klinikai vizsgálatok többsége kimutatta, hogy a gyulladás kiterjedése és súlyossága a terhesség során fokozódik. $\mathrm{Az}$ ínylaesio súlyossági foka az enyhe ínygyulladástól a fájdalmas és súlyos vérzéssel társuló ínygyulladásig, valamint súlyos ínyhyperplasiáig terjed. A gingivitis a második és a harmadik trimeszter között a legsúlyosabb. A gyulladás sokkal súlyosabb a frontfogak területén, és az interdentalis papilla mindig jobban érintett. Bár a gyulladás mértékét alapvetően a várandós nő szájhigiéniája határozza meg, még tökéletes szájhigiénia és alacsony supragingivalisplakk-értékek mellett is emelkedik a gingiva folyadéktartalma, fokozódik a sulcusváladék (exsudatum) mennyisége. Az ínyvérzési hajlam egészen a szülésig emelkedik [12]. A pontos mechanizmus, hogy milyen módon felelnek a terhességi hormonok az ínyelváltozásokért, még a mai napig sem teljesen tisztázott. Különböző hipotézisek születtek. Ezek között említhető a biofilm-összetétel megváltozása, a várandós anya relatív immunszuppressziója, az ínyszövet fokozott vascularisatiója és a megemelkedett sulcusváladék-termelés, valamint egyéb szöveti változások. A parodontalis reakciók valószínúleg nem egyetlen oki tényező, hanem multifaktoriális hatások következményei [11].

\section{A parodontalis gyulladás és a terhességi komplikációk kapcsolata}

Galloway már 1931-ben leírta, hogy a fogágybetegséget előidéző Gram-negatív kórokozók káros hatással lehetnek a terhességre és a magzat fejlődésére [11]. Az 1990es évek közepén már számos eset-kontroll és keresztmetszeti vizsgálat mutatott ki összefüggést a rossz parodontalis status és a cardiovascularis betegségek incidenciája között [5]. Ezek ismeretében Collins és mtsai 1994-ben aranyhörcsögökön vizsgálták, hogy a vemhesség 8. napján alkalmazott egyszeri intravénás endotoxininjekció (Escherichia coli és P. gingivalis) milyen hatással van a fejlődő magzatokra. Az egyszeri endotoxininjekció a dózistól függő mértékben súlyos magzatkárosodást okozott, és emelkedett a halva született egyedek száma [13]. Ugyanez a munkacsoport egy másik állatkísérletben a vemhesség 8 . napján subcutan szöveti rezervoártartályba inokulált $P$. gingivalis bakteriális endotoxin által kivál- 
tott lokális gyulladás hatását vizsgálták a vemhesség kimenetelére. A szöveti kamrában öt nappal később szignifikáns mértékben nőtt a $\mathrm{PGE}_{2}(4,7 \mathrm{pg} / \mathrm{ml}-362 \mathrm{pg} / \mathrm{ml})$ és a $\mathrm{TNF} \alpha(26,4 \mathrm{pg} / \mathrm{ml}-724 \mathrm{pg} / \mathrm{ml})$ koncentrációja, és szignifikánsan emelkedett a halva született fetusok aránya, továbbá az élve születettek testsúlya szignifikánsan alacsonyabb volt, mint a kontrollcsoportban [14]. Az emelkedett $\mathrm{PGE}_{2}$ - és TNF $\alpha$-szint és a fetus súlyának csökkenése, valamint az embriópusztulás gyakorisága között szignifikáns összefüggést találtak. A kísérleti eredmények szerint tehát egy távoli anaerob baktérium okozta lokális infekció is képes magzati károsodást okozni. Egy másik kísérletben, aranyhörcsögmodellben a tesztcsoportban P. gingivalis-inokulációval experimentális parodontitist idéztek elő, és a kontrollcsoporthoz képest szignifikánsan emelkedett az amnion-TNF $\alpha$ - és - $\mathrm{PGE}_{2}$-koncentráció, és szignifikánsan csökkent az átlagos alomsúly, valamint nőtt a halvaszületések aránya [15].

Tudományosan megalapozott bizonyítékok alapján elsőnek Offenbacher és mtsai (1996) 124 várandós és post partum nő bevonásával végzett vizsgálata alapján vetették fel, hogy a fogágybetegség az alacsony testsúlyú koraszülés egyik független rizikófaktora lehet. Az eredmények alapján a parodontitisben szenvedő anyákban még a szerzők számára is meglepő, 6,7 körüli korrigált rizikófaktor-emelkedést kalkuláltak [2, 16]. Egy 1998-as kelet-londoni vizsgálat azonban rámutatott arra, hogy csak magas, 800 körüli esetszám mellett lehet valóban szignifikáns különbségeket biztonsággal kimutatni [17].

Az 1990-es évek második felében több olyan esetkontroll és keresztmetszeti közlemény jelent meg, amely a fogágybetegséget és a koraszülést kapcsolatba hozta [15-20]. Ezek többsége valamilyen fokon pozitív korrelációt talált a parodontalis góc és a különböző terhességi komplikációk incidenciája között, azonban több vizsgálat negatív eredménnyel zárult [11, 17, 21-23]. Ezt követően az elmúlt két évtizedben is több száz eset-kontroll, keresztmetszeti és követéses progresszív epidemiológiai vizsgálat született, keresve az összefüggést a várandós anya parodontalis állapota és a terhességi komplikációk, azaz az alacsony születési testsúly és a szülés időpontja között [23]. Az eredmények továbbra is ellentmondásosak voltak. Ennek okai elsősorban a különböző etnikai, szociális-gazdasági csoportokban, illetve az eltérő vizsgálómódszerekben keresendők. A parodontitis megfelelő definíciója alapján végzett epidemiológiai vizsgálatok azonban egyértelmû pozitív korrelációt találtak a várandós nők parodontalis állapota és a terhesség kimenetele között. A legerősebb összefüggés az aktuális gyulladásos paraméterek, azaz a tasakmélység és az ínyvérzés mértéke és a terhességi komplikációk között állt fent $[5,11,15,16,20,24-27]$. Ugyancsak szignifikáns összefüggést mutattak ki a várandós anya parodontalis gyulladása és a praeeclampsia incidenciája között [28-31]. Hazánkban Radnai, Gorzó és munkatársaik szignifikáns összefüggést találtak kezdődő parodontitis és az alacsony testsúlyú koraszülések incidenciája között
[25-27]. Az utóbbi években több szisztematikus elemző közlemény foglalta ismét össze az epidemiológiai vizsgálatok eredményeit, amelyek szerint a várandós nő rossz parodontalis statusa a terhességi komplikációk egyik független rizikófaktora $[11,22-24,32]$.

\section{A parodontalis infekció és a terhességi komplikációk feltételezett patomechnizmusa}

Jelenlegi irodalmi ismereteink szerint a parodontalis góc három különböző módon okozhat akut vagy krónikus szisztémás komplikációkat a szervezetben: metasztatikus infekció, direkt szöveti sérülés és metasztatikus gyulladás útján. Ezek külön-külön vagy együtt játszhatnak szerepet a terhességi komplikációk patomechanizmusában is $[11,22]$.

Metasztatikus fertözés - A parodontalis tasakból a patogén baktériumok a vérkeringéssel metasztatikus úton a placentába és az amnionfolyadékba jutva másodlagos fertőzést és gyulladást okozhatnak [33-35].

Metasztatikus kárositás - A cirkuláló mikrobák toxinjai és egyéb toxikus melléktermékei váltanak ki gyulladásos reakciót a foetoplacentalis szövetekben [34, 36, 37].

Metasztatikus gyulladás - A parodontiumból származó gyulladásos mediátorok és/vagy az anya mája által expresszált akutfázis-molekulák képesek másodlagos gyulladásos reakciót generálni a foetoplacentalis szövetekben $[11,38]$.

\section{Metasztatikus fertözés}

A krónikus infekció szerepe a koraszülésben már régóta igazolt. Nagyon sok adat mutat arra, hogy az alsó genitalis infekciók koraszüléshez vezethetnek. Ezen hatások pontos patomechanizmusa még nem világos teljesen, de feltételezhető, hogy az aszcendáló bakteriális fertőzés olyan gyulladásoscitokin-termelést indít el az amnionban, amely idő előtti szülést indukál [33, 39, 40]. Szemben azzal a korábbi állásponttal, miszerint a magzat steril körülmények között növekszik, újabb vizsgálatok rámutattak arra, hogy a foetoplacentalis szövetek még klinikailag egészséges magzatok esetében is speciális mikroflórát hordoznak [41, 42]. Az amnionfolyadék nagyon gyakran tartalmaz F. nucleatum baktériumokat. Ezek a parodontalis tasak egyik leggyakoribb és legtömegesebb obligát anaerob mikroorganizmusai $[33,36,37]$, és sokan feltételezik, hogy hematogén szóródás útján fertőzhetik az amniont [33, 35-37].

\section{Parodontalis patogének és ezek anyagcseretermékei}

Humán morfológiai és hisztológiai vizsgálatok szerint több közlemény számolt be orális baktériumok jelenlétéről a foetoplacentalis egység különböző területein [11, 
29, 41-43]. Ma már tudományosan igazolt, hogy a legtöbb parodontalis patogén baktérium képes szöveti invázióra és hematogén szóródásra [36, 37]. A gingivitis prevalenciája várandós nókben igen magas, bizonyos populációkban eléri a 90\%-ot. A nők nagy többsége már terhesség elött is krónikus gingivitisben vagy parodontitisben szenved. A plakk okozta parodontalis infekció ínygyulladáshoz és ínyvérzéshez vezet. A terhesség alatt megemelkedett nemihormon-szint még tovább növeli a gyulladásos reakciót, mivel fokozza az érpermeabilitást és az ödémaképződést. Ennek hatására tovább mélyül az ínytasak, és a subgingivalis bakteriális flóra még inkább anaerob irányba tolódik el. Ez a két faktor együtt a terhesség alatt elősegíti a hematogén szóródást [5].

A parodontalis tasakban legnagyobb százalékban előforduló obligát anaerob, a $F$. nucleatum kimutatható volt a placentában praeeclampsiás anyákban [29], illetve alacsony testsúlyú koraszülés esetén is [43]. Egy 2014-es mikrobiológiai vizsgálat szerint 320 placenta-szövetmintából származó mikrobiológiai lelet sokkal jobban hasonlított a nem várandós anyák orális mikroflórájára, mintsem a kontrollnők urogenitalis traktusának vagy a végbélnyílásukból nyert székletmintának a baktériumösszetételére. Ez a nagyfokú egyezés általánosságban azt támasztja alá, hogy a szájüreg és a foetoplacentalis szövetek között bakteriális transzmisszó létezik [4l]. A legújabb eset-kontroll vizsgálatok PCR- (polimeráz-láncreakció) technikával kimutatták, hogy a placenta az anya parodontalis statusától függetlenül tartalmazhat orális mikroorganizmusokat. A különböző parodontalis patogén baktériumok aránya azonban szignifikánsan magasabb a parodontitisben szenvedő nők körében, mint a parodontalisan egészségesekben $[43,44]$. Chaparro és mtsai (2013) várandós nók között összefüggést mutattak ki a placentában jelen lévő $P$. gingivalis és $T$. denticola mennyisége és a praeeclampsia és gestatiós hypertensio között [44]. Egy másik vizsgálat szerint krónikus parodontitisben a P.gingivalis, a T. forsythia és az Eikenella corrodens subgingivalis jelenléte szignifikáns korrelációt mutatott a praeeclampsia incidenciájával [30]. Egy másik vizsgálatban pedig az E. corrodens és a Capnocytophaga spp. jelenléte mutatott szoros kapcsolatot alacsony testsúlyú koraszüléssel [45]. Egy japán populáción végzett vizsgálat szerint a subgingivalis biofilm $A$. actinomycetemcomitans-mennyisége és a praeeclampsia előfordulása között szignifikáns korreláció volt [31]. Más vizsgálatok azonban nem mutattak ki pozitív korrelációt a parodontitis és az alacsony testsúlyú koraszülés között, bár a koraszülő anyákban szignifikánsan magasabb volt a subgingivalis Capnocytophaga ochracea, a Parvimonas micra, a Streptococcus oralis, a Streptococcus sanguinis, a T. denticola és a T. forsythia koncentrációja, mint a normálidőben szülő anyákban [46]. Egy másik vizsgálat szerint 26 veszélyeztetett várandós nő közül nyolcban $(30,8 \%)$ a magzatvíz P. gingivalissal volt fertôzött [47]. Ugyanakkor egy spanyol vizsgálat szerint annak ellenére, hogy a parodontitis prevalenciája sokkal magasabb volt a kora- szülő anyákban, mint a normálidőben szülőkk körében, összességében nem volt szignifikáns különbség a subgingivalis bakteriális flóra összetételében [48].

Az első praeeclampsia komplett mikrobiomvizsgálatban Amarasekara és mtsai (2015) 110 egészséges és praeeclampsiás nő placentamintáit dolgozták fel. Az 55 praeeclampsiás nőből hét $(12,7 \%)$ esetében a PCR pozitív eredményt adott orális mikroorganizmusokra, szemben az összes egészséges nőből (kontroll) származó 55 placentamintával, amely mind negatív volt [28]. Ugyanakkor ebben a vizsgálatban a hematogén szóródás tényét nem tudták igazolni, mivel egyik fentebb említett ágens sem volt kinyerhető az anya vénás véréből vagy a vizeletéből a szülés vagy a császármetszés pillanatában [28].

Vemhes egereken végzett kísérletek szerint az intravénásan beadott $F$. nucleatum specifikus módon kolonizálta a foetoplacentalis szöveteket, és ott elszaporodott, ugyanakkor direkt a deciduumba adott injekció chorioamnionitist okozott. Mind a két eset végezetül magzati károsodáshoz vagy halvaszületéshez vezetett [36]. Egy másik vizsgálatban egerek mesterséges $P$. gingivalis és $C$. rectus parodontalis infekciója után ezek a baktériumok a placentában megjelentek, ami végül alacsony testsúlyú koraszüléshez vezetett [49].

Ugyanakkor ma még megoldásra váró kérdés, hogy miért alakul ki bizonyos anyákban terhességi komplikáció, míg másokban a placenta bakteriális kolonizációja ellenére is komplikációmentes szülés zajlik le. Ennek értelmében ma még nagyon nehéz megmondani, hogy milyen faktorok járulnak hozzá a terhességi komplikációkhoz olyankor, amikor orális baktériumok jelen vannak a foetoplacentalis szövetekben. Még az sem világos, hogy milyen a baktériumok koaggregációs és biofilmképző képessége az amnionüregben [50]. Következésképpen ezen a területen további jól kontrollált klinikai vizsgálatokra van szükség.

\section{Gyulladásos citokinek}

Parodontitisben szignifikánsan emelkedik a tasak gyulladásoscitokin-koncentrációja, és egyben a szisztémás gyulladásos mediátorok szintje is magasabb, mint egészséges egyénekben [51]. Több vizsgálat kimutatta, hogy koraszülő anyák körében sokkal rosszabb volt a parodontalis status, és a sulcusváladékban szignifikánsan magasabb volt az ILI $\beta$ és a PGE 2 szintje a normálidőben szülő anyák értékeihez képest. Egy várandós nők körében a közelmúltban végzett eset-kontroll vizsgálatban kimutatták, hogy egészséges parodontiumú várandós anyákkal összehasonlítva, az IL4- és a TNF $\alpha$ szérumértékek is szignifikánsan magasabbak voltak azokban, akiknek gingivitise vagy parodontitise volt [52]. A TNF $\alpha$-szint azonban szignifikánsan alacsonyabb volt olyan, parodontitisben szenvedő várandós anyákban, akikben a második trimeszter kezdetén praeeclampsia fejlődött ki [52]. 
Egy másik vizsgálat szerint a parodontitisben szenvedő várandós anyák sulcus-ILl $\beta$-, -IL6-, -TNF $\alpha$ - és - $\mathrm{PGE}_{2}$-értékei szignifikánsan magasabbak voltak és a szérum-TNF $\alpha$ - és - $\mathrm{PGE}_{2}$-szint is magasabb volt, mint a parodontalisan egészséges kontrollokban [51]. Ezek a vizsgálati eredmények arra mutatnak, hogy esetleg a fogágybetegség a megemelkedett szisztémás gyulladásos és potenciálisan abortív faktorok (ILl $\beta$, IL6, TNF $\alpha$ és $\mathrm{PGE}_{2}$ ) útján játszhat szerepet a praeeclampsia és a terhességi komplikációk patogenezisében $[51,52]$.

A gyulladásos citokinek - IL1, IL6 és TNF $\alpha$ - fokozzák az endogénprosztaglandin-termelést a chorionban, és e szérumértékek és a magasabb amnionértékek összefüggésbe hozhatók voltak amnionitisszel és korai magzatburok-repedéssel [53]. Elméletileg a parodontalis szövetekben keletkező magasabb $\mathrm{PGE}_{2}$-szint is hozzájárulhat a chorionban a $\mathrm{PGE}_{2}$-szint emelkedéséhez, de sokkal inkább a szisztémás keringésbe jutó baktériumok és gyulladásos citokinek váltanak ki lokálisan fokozott $\mathrm{PGE}_{2}$-termelést, ami végül méhnyaktáguláshoz és uteruskontrakcióhoz vezet. Ma azonban még nincsenek megcáfolhatatlan bizonyítékok arra vonatkozóan, hogy parodontitises páciensekben a tasak megemelkedett gyulladásos faktorai vagy a magasabb szérum-és amnionértékek ok-okozati összefüggésbe hozhatók lennének terhességi komplikációkkal $[11,51,52]$.

\section{C-reaktín protein}

A fertőzött parodontalis szövetekből felszabaduló baktériumok és gyulladásos citokinek a szisztémás keringésbe jutva akutfázis-reakciót válthatnak ki a májban, ami akutfázis-fehérjék (C-reaktív protein - CRP) és fibrinogén fokozott felszabadulásához vezet $[11,53]$. Parodontitisben átlagosan 1-1,5 mg/1 CRP-szint-emelkedést mutattak ki. Ennek ma már komoly szerepet tulajdonítanak a thromboemboliás kórképek patogenezisében is [54]. A mérsékelt/súlyos parodontitis és a megemelkedett szisztémás szérum-CRP-szint között kapcsolatot mutattak ki afroamerikai nókben [11]. Miután a CRP a cirkuláció útján elterjed az egész szervezetben, ez elvileg járulékos módon intrauterin gyulladást is produkálhat $[11,53]$.

A magasabb CRP-szintet is kapcsolatba hozták sok, fertőzés keltette intrauterin gyulladásos folyamattal. Terhesség során a magasabb szérum-CRP-koncentráció a foetoplacentalis szövetekben gyulladásos válaszreakciót generálhat, komplementaktiváció, direkt szövetkárosodás és a lokálisan termelődő proinflammatorikus citokintermelés stimulálása révén [55]. Keresztmetszeti vizsgálatok parodontitisben szenvedő várandós anyák megemelkedett CRP-értékeit összefüggésbe hozták koraszüléssel $[51,55,56]$ vagy praeeclampsiával $[11,52]$.

\section{Immunglobulinok}

Az anyai és magzati orális patogénellenes immunválaszt illetően csak kevés vizsgálat született $[23,57]$. Parodon- titises várandós nók immunológiai vizsgálata szerint azokban az anyákban, akikben a tasakban lévő anaerob patogén baktériumok (P. gingivalis, T. forsythia, Prevotella intermedia) elleni szisztémás IgG-titer alacsony volt, szignifikánsan erósebb volt a tasakbaktériumok szóródása és a fetusok fertőződése $[5,11]$.

Egy nagy amerikai terhességi követéses vizsgálatban a post partum anyák parodontalis patogén antigénekkel szembeni szérum-IgG-szintjének alakulását és a fetus bakteriális expozícióját a köldökzsinórvér IgM-ellenanyag-titere alapján vizsgálták [23]. A koraszülöttek között 2,9-szer volt gyakoribb az orális anaerob baktériummal szembeni IgM-szeropozitivás, mint az egészséges kontrollokban $[22,23]$. A legmagasabb arányban azoknál az anyáknál fordult elő koraszülés, akikben nem fejlődött ki az obligát parodontalis anaerobok elleni IgGválasz, viszont a magzati specifikus IgM-ellenanyag-szint magas volt $[22,23]$. Ezeket az eredményeket megerósítik Ebersole és munkatársainak (2009) vizsgálatai, amelyek a normálidőben szülő kontrollanyákhoz viszonyítva a koraszülő anyákban szignifikánsan alacsonyabb $P$.gingivalis-ellenes szérum-IgG-szintet mutattak ki [57]. Miután az anyai IgM nem tud átjutni a placentabarrieren, jelenlétük másként nem magyarázható, mint hogy a baktériumok vagy antigénjeik a magzatba bejutva indukáltak IgM típusú immunválaszt [23]. Azonban több, a fentieknek ellentmondó közlemény is megjelent, amelyekben a vizsgálatok nem tudtak különbséget kimutatni a szérum-ellenanyagszintekben koraszülő és normálidőben szülő anyák között $[58,59]$.

A fenti adatok alapján felállítható egy olyan hipotézis, amely további igazolásra szorul, miszerint a várandós anya alacsony parodontalisbaktérium-ellenes szisztémás ellenanyagszintje elősegíti, hogy a baktériumok könnyebben jussanak a foetoplacentalis szövetekbe, és okozzanak terhességi komplikációt. Ugyanakkor a megemelkedett szérum-IgG-ellenanyag-szint az úgynevezett „hyper-inflammatory” fenotípusnak is lehet a jele, amely a várandós anyákat fokozott foetoplacentalis gyulladásra vagy magzatkárosodásra hajlamosítja [22, 23].

Kérdés, hogy milyen prevenciós és terápiás lépések előzhetik meg a parodontalis góc negatív magzati hatásait. Az intervenciós klinikai vizsgálatok arra mutatnak, hogy azokban a parodontitisben szenvedő nókben, akiknél a terhesség előtt adekvát parodontalis kezelést kezdtek el, lényegesen kisebb arányban fordult elő koraszülés, mint a nem kezelt kontrollcsoportban [60-62]. Azonban a legtöbb metaanalízis szerint a terhesség második-harmadik trimeszterében végzett nem sebészi parodontalistasak-kezelésnek nincs pozitív hatása a terhességi komplikációkra $[63,64]$. Ugyanakkor a veszélyeztetett terhesek csoportján végzett nem sebészi parodontalis kezelés csökkentette a koraszülés incidenciáját [65]. 


\section{Következtetés}

Fontos megjegyezni, hogy a legtöbb vizsgálat, amelyben pozitív összefüggést találtak a parodontalis status és az alacsony testsúlyú koraszülések között, szociálisan hátrányos helyzetben lévő populáció vizsgálatából született, olyan populációban, amelyben egyébként is magasabb a koraszülések kockázata [15, 17-20, 59, 66]. Ezzel szemben a jobb szociális helyzetben lévő csoportokon végzett vizsgálatokban lényegesen gyengébb összefüggés mutatkozott a parodontalis gyulladás és a perinatalis komplikációk gyakorisága között [21, 67]. Így feltételezhető, hogy a parodontalis infekció magzati hatása nagyban függ számos magatartási rizikótényezőtől, az adott populáció átlagéletkorától, általános szociális és családi helyzetétől és az egészségügyi szolgáltatás színvonalától [68-70].

A jelenlegi klinikai bizonyítékok többsége keresztmetszeti és eset-kontroll vizsgálatokból született. A tárgyalt klinikai vizsgálatok és egyes állatmodellek kibővítették mai tudásunkat a parodontalis gyulladás és a terhességi komplikációk közötti kapcsolatok lehetséges biológiai mechanizmusáról. Érdekes módon a szájüregi normál commensalis és patogén baktériumok képesek a foetoplacentalis szövetek kolonizációjára, mind időben szülő, mind pedig koraszülő anyákban. A parodontium és a foetoplacentalis szövetek közötti kapcsolatnak a legvalószínúbb útja az orális baktériumok hematogén szóródása. Bár bizonyos anaerob parodontalis patogén baktériumok összefüggésbe hozhatók praeeclampsiával [30, 31], koraszüléssel $[20,26,27,39,51,66]$, chorioamnionitisszel és/vagy halvaszületéssel [36, 37], nagyon keveset tudunk ezek pontos szerepéról a terhességi komplikációk etiopatogenezisében és patomechanizmusában [11, 63]. Ahhoz, hogy jobban megértsük a komplex biológiai folyamatokat a terhesség egésze alatt, valamint a baktériumok pontos szerepét a terhességi komplikációk etiopatogenezisében, további jól tervezett randomizált longitudinális követéses vizsgálatokra van szükség. Ma úgy tünik, hogy parodontitisben nincs egyetlen olyan mikrobiológiai vagy immunbiomarker sem, amely megjósolhatná a terhességi komplikációk veszélyét [11, 22, 23].

Anyagi támogatás: A közlemény megírása, illetve a kapcsolódó kutatómunka anyagi támogatásban nem részesült.

A szerző a cikk végleges változatát elolvasta és jóváhagyta.

Érdekeltségek: A szerzőnek nincsenek érdekeltségei.

\section{Irodalom}

[1] Miller WD. The human mouth as a focus of infection. Dent Cosmos 1891; 33: 689-713.

[2] Offenbacher S, Katz V, Fertik G. Periodontal infection as a risk factor for preterm low birth weight. J Periodontol. 1996; 67: 1103-1113.

[3] Párkányi L, Vályi P, Nagy K, et al. Odontogenic foci and systemic diseases. A review. [Az odontogén góc és a szisztémás betegségek. Irodalmi áttekintés.] Orv Hetil. 2018; 159: 415422. [Hungarian]

[4] Scannapieco FA. Position paper of the American Academy of Periodontology: periodontal disease as a potential risk factor for systemic diseases. J Periodontol. 1998; 69: 841-850.

[5] Gera I. Gorzó I. Periodontal disease as a risk factor for systemic diseases. In: Gera I. (ed.) Periodontology. 2nd edn. [A fogágybetegség mint az általános szervezeti betegségek rizikófaktora Parodontális Medicina. In: Gera I. (szerk.) Parodontológia. 2. kiadás.] Semmelweis Kiadó, Budapest, 2009; pp. 203-215. [Hungarian]

[6] Hajishengallis G, Lamont RJ. Beyond the red complex and into more complexity: the polymicrobial synergy and dysbiosis (PSD) model of periodontal disease etiology. Mol Oral Microbiol. 2012; 27: 409-419.

[7] Könönen E, Paju S, Pussinen PJ, et al. Population based study of salivary carriage of periodontal pathogens in adults. J Clin Microbiol. 2007; 45: 2446-2451.

[8] Stingu CS, Jentsch H, Eick S, et al. Microbial profile of patients with periodontitis compared with healthy subjects. Quintessence Int. 2012; 43: e23-e31.

[9] Van Dyke TE, Van Winkelhoff AJ. Infection and inflammatory mechanisms. J Clin Periodontol. 2013; 40(Suppl 14): S1-S7.

[10] Hajishengallis G. Periodontitis: from microbial immune subversion to systemic inflammation. Nat Rev Immunol. 2015; 15: $30-44$.

[11] Gürsoy M, Graziani F. Biological mechanisms between periodontal diseases and pregnancy complications. Oral Health and Pregnancy: oralhealthandpregnancy.efp.org 2018.

[12] Wu M, Chen SW, Su WL, et al. Sex hormones enhance gingival inflammation without effecting IL- $1 \beta$ and TNF- $\alpha$ in periodontally healthy women during pregnancy. Mediators Inflamm. 2016; 2016: 4897890 .

[13] Collins JG, Windley HW, Arnold RR, et al. Effects of Porphyromonas gingivalis infection on inflammatory mediator response on pregnancy outcome in hamsters. Infect Immun. 1994; 62: $4356-4361$.

[14] Collins JG, Smith MA, Arnold RR, et al. Effects of Escherichia coli and Porphyromonas gingivalis lipopolysaccharide on pregnancy outcome in golden hamsters. Infect Immum. 1994; 62: $4652-4655$.

[15] Offenbacher S, Jared HL, O'Reilly PG, et al. Potential pathogenic mechanisms of periodontitis associated pregnancy complications. Ann Periodontol. 1998; 3: 233-250.

[16] Offenbacher S, Zambon JJ. Consensus report for periodontal disease: pathogenesis and microbial factors. Ann Periodontol. 1996; 1: 926-932.

[17] Davenport ES, Williams CE, Sterne JA, et al. The East London study of maternal chronic periodontal disease and preterm low birth weight infants: study design and prevalence data. Ann Periodontol. 1998; 3: 213-221.

[18] Dasanayake AP. Poor periodontal health of the pregnant woman as a risk factor for low birth weight. Ann Periodontol. 1998; 3 : 206-212. 
[19] Jeffcoat MK, Geurs NC, Reddy MS, et al. Current evidence regarding periodontal disease as a risk factor in preterm birth. Ann Periodontol. 2001; 6: 183-188.

[20] Offenbacher S, Beck JD, Lieff S, et al. Role of periodontitis in systemic health: spontaneous preterm birth. J Dent Educ. 1998; 62: 852-858.

[21] Holbrook WP, Óskarsdóttir A, Fridjónsson T, et al. No link between low-grade periodontal disease and preterm birth: a pilot study in a healthy Caucasian population. Acta Odont Scand. 2004; 62: 177-179.

[22] Madianos PN, Bobetsis YA, Offenbacher S. Adverse pregnancy outcomes (APOs) and periodontal disease: pathogenic mechanisms. J Clin Periodontol. 2013; 40(Suppl 14): S170-S180.

[23] Madianos PN, Lieff S, Murtha AP, et al. Maternal periodontitis and prematurity. Part II: Obstetric outcome of prematurity and growth restriction. Ann Periodontol. 2001; 6: 164-174.

[24] Offenbacher S, Lieff S, Boggess KA, et al. Maternal periodontitis and prematurity. Part I: Maternal infections and fetal exposure. Ann Periodontol. 2001; 6: 175-182.

[25] Radnai M, Gorzó I. Periodontal diseases as a potential risk factor for preterm birth and low birth weight (literature review). [A fogágybetegség mint a koraszülés és a kis súlyú újszülött születésének lehetséges rizikófaktora (irodalmi áttekintés).] Fogorv Szle. 2002; 95: 241-244. [Hungarian]

[26] Radnai M, Gorzo I, Nagy E, et al. A possible association between preterm birth and early periodontitis. A pilot study. J Clin Periodontol. 2004; 31: 736-741.

[27] Radnai M, Gorzó I, Urbán E, et al. Possible association between mother's periodontal status and preterm delivery. J Clin Periodontol. 2006; 33: 791-796.

[28] Amarasekara R, Jayasekara RW, Senanayake H, et al. Microbiome of the placenta in pre-eclampsia supports the role of bacteria in the multifactorial cause of pre-eclampsia. J Obstet Gynaecol Res. 2015; 41: 662-669.

[29] Barak S, Oettinger-Barak O, Machtei EE, et al. Evidence of periopathogenic microorganisms in placentas of women with preeclampsia. J Periodontol. 2007; 78: 670-676.

[30] Contreras A, Herrera JA, Soto JE, et al. Periodontitis is associated with preeclampsia in pregnant women. J Periodontol. 2006; 77: 182-188.

[31] Hirano E, Sugita N, Kikuchi A, et al. The association of Aggregatibacter actinomycetemcomitans with preeclampsia in a subset of Japanese pregnant women. J Clin Periodontol. 2012; 39: 229-238.

[32] Sanz M, Kornman K. Periodontitis and adverse pregnancy outcomes: consensus report of the Joint EFP/AAP Workshop on Periodontitis and Systemic Diseases. J Clin Periodontol. 2013; 40(Suppl 4): S164-S169.

[33] Gauthier S, Tétu A, Himaya E, et al. The origin of Fusobacterium nucleatum involved in intra-amniotic infection and preterm birth. J Matern Fetal Neonatal Med. 2011; 24: 1329-1332.

[34] Han YW, Shen T, Chung P, et al. Uncultivated bacteria as etiologic agents of intra-amniotic inflammation leading to preterm birth. J Clin Microbiol. 2009; 47: 38-47.

[35] Urbán E, Radnai M, Novák T, et al. Distribution of anaerobic bacteria among pregnant periodontitis patients who experience preterm delivery. Anaerobe 2006; 12: 52-57.

[36] Han YW, Redline RW, Li M, et al. Fusobacterium nucleatum induces premature and term stillbirths in pregnant mice: implication of oral bacteria in preterm birth. Infect Immun. 2004; 72: 2272-2279.

[37] Han YW, Fardini Y, Chen C, et al. Term stillbirth caused by oral Fusobacterium nucleatum. Obstet Gynecol. 2010; 115: 442445 .

[38] Taylor BD, Ness RB, Klebanoff MA, et al. First and second trimester immune biomarkers in preeclamptic and normotensive women. Pregnancy Hypertens. 2016; 6: 388-393.
[39] Eschenbach DA, Gravett MG, Chen KCS, és et al. Bacterial vaginosis during pregnancy. An association with prematurity and postpartum complications. Scand J Urol Nephrol. 1985; 19(Suppl 86): 213-222.

[40] Hay PE, Lamont RF, Taylor-Robinson D, et al. Abnormal bacterial colonialisation of the genital tract and subsequent preterm delivery and late miscarrige. Br Med J. 1994; 308: 295-298.

[41] Aagaard K, Ma J, Antony KM, et al. The placenta harbors a unique microbiome. Sci Transl Med. 2014; 6: $237 \mathrm{ra65}$.

[42] Stout MJ, Conlon B, Landeau M, et al. Identification of intracellular bacteria in the basal plate of the human placenta in term and preterm gestations. Am J Obstet Gynecol. 2013; 208: 226.el226.e7.

[43] Blanc V, O'Valle F, Pozo E, et al. Oral bacteria in placental tissues: increased molecular detection in pregnant periodontitis patients. Oral Dis. 2015; 21: 905-912.

[44] Chaparro A, Blanlot C, Ramírez V, et al. Porphyromonas gingivalis, Treponema denticola and toll-like receptor 2 are associated with hypertensive disorders in placental tissue: a case-control study. J Periodontal Res. 2013; 48: 802-809.

[45] Santa Cruz I, Herrera D, Martin C, et al. Association between periodontal status and pre-term and/or low-birth weight in Spain: clinical and microbiological parameters. J Periodontal Res. 2013; 48: 443-451.

[46] Skuldbøl T, Johansen KH, Dahlén G, et al. Is pre-term labour associated with periodontitis in a Danish maternity ward? J Clin Periodontol. 2006; 33: 177-183.

[47] León R, Silva N, Ovalle A, et al. Detection of Porphyromonas gingivalis in the amniotic fluid in pregnant women with a diagnosis of threatened premature labor. J Periodontol. 2007; 78: 1249-1255.

[48] Mesa F, Pozo E, Blanc V, et al. Are periodontal bacterial profiles and placental inflammatory infiltrate in pregnancy related to birth outcomes? J Periodontol. 2013; 84: 1327-1336.

[49] Ao M, Miyauchi M, Furusho H, el al. Dental infection of Porphyromonas gingivalis induces preterm birth in mice. PLoS ONE 2015; 10: e0137249.

[50] Romero R, Schaudinn C, Kusanovic JP, et al. Detection of a microbial biofilm in intraamniotic infection. Am J Obstet Gynecol. 2008; 198: 135.el-135.e5.

[51] Perunovic ND, Rakic MM, Nikolic LI, et al. The association between periodontal inflammation and labor triggers (elevated cytokine levels) in preterm birth: a cross-sectional study. J Periodontol. 2016; 87: 248-256.

[52] Kumar A, Begum N, Prasad S, et al. Role of cytokines in development of pre-eclampsia associated with periodontal disease - co- $^{-}$ hort study. J Clin Periodontol. 2014; 41: 357-365.

[53] Park CW, Yoon BH, Park JS, et al. An elevated maternal serum C-reactive protein in the context of intra-amniotic inflammation is an indicator that the development of amnionitis, an intense fetal and AF inflammatory response are likely in patients with preterm labor: clinical implications. J Matern Fetal Neonatal Med. 2013; 26: 847-853.

[54] Paraskevas S, Huizinga JD, Loos BG. A systematic review and meta-analyses on $\mathrm{C}$-reactive protein in relation to periodontitis. J Clin Periodontol. 2008; 35: 277-290.

[55] Sharma A, Ramesh A, Thomas B. Evaluation of plasma C-reactive protein levels in pregnant women with and without periodontal disease: a comparative study. J Indian Soc Periodontol. 2009; 13: 145-149.

[56] Pitiphat W, Gillman MW, Joshipura KJ, et al. Plasma C-reactive protein in early pregnancy and preterm delivery. Am J Epidemiol. 2005 ; 162: 1108-1113.

[57] Ebersole JL, Novak MJ, Michalowicz BS, et al. Systemic immune responses in pregnancy and periodontitis: relationship to pregnancy outcomes in the Obstetrics and Periodontal Therapy (OPT) study. J Periodontol. 2009; 80: 953-960. 
[58] Dasanayake AP, Boyd D, Madianos PN, et al. The association between Porphyromonas gingivalis-specific maternal serum IgG and low birth weight. J Periodontol. 2001; 72: 491-497.

[59] Jarjoura K, Devine PC, Perez-Delboy A, et al. Markers of periodontal infection and preterm birth. Am J Obstet Gynecol. 2005; 192: 513-519.

[60] López NJ, Da Silva I, Ipinza J, et al. Periodontal therapy reduces the rate of preterm low birth weight in women with pregnancyassociated gingivitis. J Periodontol. 2005; 76(Suppl): 21442153.

[61] López NJ, Smith P, Gutierrez J. Periodontal therapy reduces the risk of preterm low birth weight. J Dent Res. 2001; 80(1 Suppl): 188 (Abstr. 1223).

[62] López NJ, Smith PC, Gutierrez J. Periodontal therapy may reduce the risk of preterm low birth weight in women with periodontal disease: a randomized controlled trial. J Periodontol. 2002; 73: 911-924.

[63] Michalowicz BS, Gustafsson A, Thumbigere-Math V, et al. The effects of periodontal treatment on pregnancy outcomes. J Clin Periodontol. 2013; 40(Suppl 14): S195-S208.

[64] Offenbacher S, Beck JD, Jared HL, et al. Effects of periodontal therapy on rate of preterm delivery: a randomized controlled trial. Obstet Gynecol. 2009; 114: 551-559.

[65] Radnai M, Pál A, Novák T, et al. Benefits of periodontal therapy when preterm birth threatens. J Dent Res. 2009; 88: 280-284.
[66] López NJ, Smith PC, Gutierrez J. Higher risk of preterm birth and low birth weight in women with periodontal disease. J Dent Res. 2002; 81: 58-63.

[67] Meurman JH, Furuholm J, Kaaja R, et al. Oral health in women with pregnancy and delivery complications. Clin Oral Investig. 2006; 10: 96-101.

[68] Szele ASz, Nagy BE. The connection between maltreatment and preterm birth - in the light of psychomotor development at 2 years old. [A bántalmazás és a koraszülés összefüggései a kétéves kori pszichomotoros fejlődés tükrében.] Orv Hetil. 2017; 158: 976-983. [Hungarian]

[69] Szita B, Baji I, Rigó J Jr. Psychosocial aspects of preeclampsia. [A praeeclampsia pszichoszociális vonatkozásai.] Orv Hetil. 2015; 156: 2028-2034. [Hungarian]

[70] Vanya M, Sili K, Devosa I, et al. Risk of maternal and fetal disease among women older than 40 years. [Magzati és anyai betegségek kockázata 40 évesnél idôsebb édesanyák esetében.] Orv Hetil. 2015; 156: 1987-1990. [Hungarian]

(Gera István dr., Budapest, Szentkirályi u. 47., 1088 e-mail: gera.istvan@dent.semmelweis-univ.hu)

\section{„Cum dabitur sonipes gratis, non inspice dentes!" (Ajándék lónak ne nézd a fogát!)}

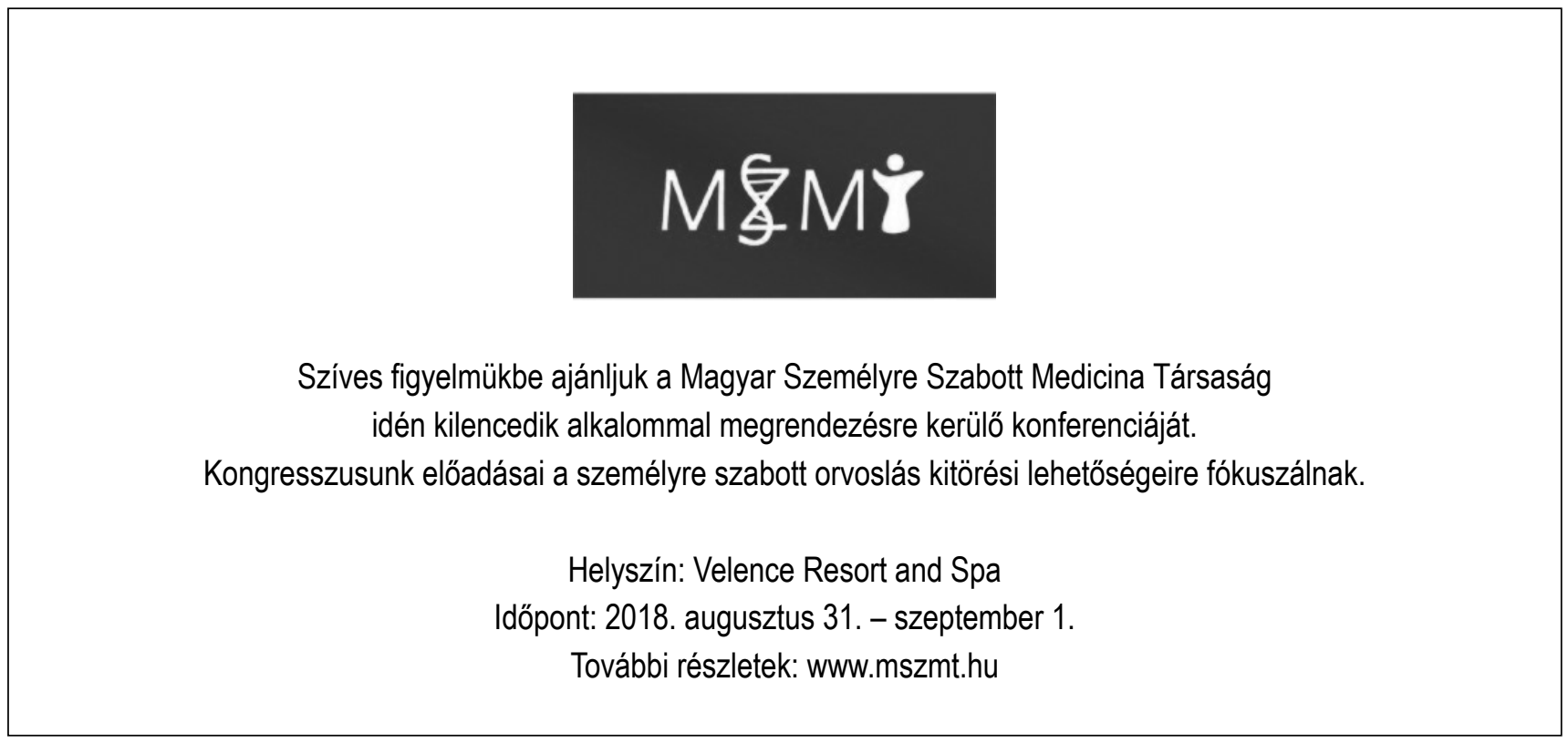

